\title{
Finance: An Islamic Perspective
}

\author{
K. M. Anwarul Islam ${ }^{1}$ \\ ${ }^{1}$ Department of Business Administration, The Millennium University, Dhaka, Bangladesh \\ E-mail:ai419bankingdu@gmail.com \\ Correspondence: C/O K. M. Kamal Uddin, Deputy Registrar, Registrar's office, Room No-201(K),Dhaka \\ University, Dhaka-1000, Tel: +8801768343171 .
}

Received: June 01, 2017

Accepted: July 05, 2017

Online Published: July 12, 2017

\begin{abstract}
Islamic finance was practiced predominantly in the Muslim world throughout the Middle Ages, fostering trade and business activities with the development of credit.In Spain and the Mediterranean and Baltic States, Islamic merchants became indispensable middlemen for trading activities.In fact, many concepts, techniques, and instruments of Islamic finance were later adopted by European financiers and businessmen. The aim of this research work is to examine the finance as an Islamic Perspective.
\end{abstract}

Keywords: Finance, Islam, Banking, Sharia.

\section{Introduction}

Islamic finance is that it does not allow the creation of debt through the direct lending and borrowing of money or other financial assets. The debts can only be created through the sale or lease of real assets through lease-based financing schemes (such as murabaha, ijara, and sukuk). The assets which are leased or sold must be real (building, property, or any other physical infrastructure), and the transactions must be genuine (approved by government regulators, as well as religious experts comprising the Shariah board) with the full intention of giving and taking charge, and the associated debt (risk) cannot be sold or transferred to someone else.

2. What is Shariah?

Shariah or the Islamic Law is defined as a body of divine laws, rules, code of conduct and teachings which are intended to benefit the individual and society. It refers to the Islamic canonical law based on the teachings of the Koran. This law imposes certain strictures on the types of financial and commercial activities that Muslims can engage in. While trade and investment are encouraged, Shariah investing rules prohibit involvement in businesses related to certain haram (prohibited) activities.Islamic Banking, popularly referred to as interest-free banking, has been gaining increasing popularity among the regulators in the recent past. In many Islamic countries the entire banking system is undergoing a transition from conventional banking to the new concept of interest-free banking.

The concept of Islamic banking developed on the basis of the Shariah principles. In comparison to conventional banking where interest is acceptable, in Islamic banking interest in any form is firmly forbidden.The essential feature of Islamic banking is that it is interest-free. However there is more to it i.e. contributions towards a more equitable distribution of income and wealth, and increased equity participation in the economy. 


\section{Understanding Islamic Finance}

Islamic banking is governed by the Islamic law known as Sharia that was formed some 1,400 years ago. It aims to provide banking services while staying within the Sharia boundaries. The law has been specifically formulated to eliminate malpractice and exploitation while encouraging healthy trade and commerce. While Sharia is a complete set of laws that are to be followed by every Muslim, only a restricted portion pertaining to banking transactions applies to Islamic finance.

\section{The Islamic Financial System}

Financial services that meet the requirements of the Shariah, or Islamic law are called Islamic finance. While designed to meet the specific religious requirements of Muslim customers, Islamic banking is not restricted to Muslims: both the financial services provider and the customer can be non-Muslim, as well as Muslim. Shariah-compliant financing (SCF) constitutes financial practices that conform to Islamic law.Major principles of shariah law that are applicable to finance and that differ from conventional finance are:

In conventional forms of finance, a distinction is made between acceptable interest and usurious interest (i.e., excessive rates of interest). In contrast, under Islamic law, any level of interest is considered to be usurious and is prohibited. Some question how lenders can profit from financial transactions under Islamic law. Take for instance, in a real estate setting; SCF takes the form of leasing, as opposed to loans. Instead of borrowing money, the bank obtains the property and leases it to the shariah-compliant investor, who pays rent instead of interest.

Ban on Uncertainty: Uncertainty in contractual terms and conditions is not allowed, unless all of the terms and conditions of the risks are clearly understood by all parties of a financial transaction. This condition may help eliminate most of the speculative transactions which involve gharar (excessive uncertainty).

Parties involved in a financial transaction must share both the associated risks and profits. Earnings from profits or returns from assets are permitted, so long as the business risks are shared by the lender and the borrower. This will help ensure that the seller (or lessor) also shares a part of the risks in order to be able to get a share of the returns. Once the seller (financier) acquires ownership and possession of the goods for sale or lease, he/she bears the risks.

Investment in industries that are prohibited by the Qur'an, such as alcohol, pornography, gambling, and pork based products, are discouraged.

Each financial transaction must be tied to a "tangible, identifiable underlying asset." 9 The debt cannot be sold, and thus the risk associated with it cannot be transferred to someone else; it must be borne by the creditor himself. According to this condition a transaction must be a genuine trade transaction, and the fact that the creditor cannot transfer the risk to someone else by selling off the debt, will also help eliminate speculative and derivative transactions, as well as prevent the debt from rising far above the size of the real economy.3.

\section{Key principles}

The Shariah governs all aspects of an individual's life from matters of state, such as governance and foreign relations, to issues of daily living and financial transactions. It is the set of rules and principles that Muslims believe expresses God's guidance on the way individuals should lead their lives. The Shariah is derived from two primary sources, the Quran and the Sunnah. The Quran, Muslims believe, is the word of God revealed to the Prophet Muhammad (570-632 AD). The Sunnah is the recorded collection of the sayings and practices of the Prophet Muhammad. Specific rulings are derived from these sources to create a body of law known as Fiqh. A number of accepted schools of interpretation have emerged in Islam that differs in their methodology for deriving Fiqh.

Some of the general principles are discussed below. 


\subsection{Interest (Riba)}

The Shariah prohibits Riba in transactions. Linguistically, the word Riba means "increase". In a commercial context, the Shariah concept of Riba is similar to the payment of interest in conventional financings. Riba occurs when money is lent and paid back with interest, whether fixed or floating. It also occurs when money or currency is exchanged in unequal amounts (Riba al-fadl) or in equal amounts with one or both payments deferred (Riba al-nasia). In principle, the Shariah requires that returns on capital must be linked to the success of a business venture rather than emanating from the mere act of lending money.

\subsection{Uncertainty (Gharar)}

Agreements that contain a material degree of uncertainty are not recognized as valid under the Shariah. It would not be acceptable to enter into a sale agreement, for example, where the existence or material characteristics of the assets are unknown. Therefore, care should be taken when drafting documentation to ensure that there is certainty of the relevant subject matter and any relevant payment obligations. If these foundational elements are not determined in advance, the transaction would not usually be approved as Shariah compliant.

\subsection{Speculation (Maisir)}

Transactions that rely on mere chance are not permitted under the Shariah. Returns from a business venture should result from the efforts of the parties to a transaction. On account of this prohibition, certain types of derivatives such as futures and options that are employed for speculative returns are prohibited.

\subsection{Prohibited investments (Haram)}

In addition to giving guidance on how a transaction should be structured, the Shariah stipulates that the nature of the underlying investment must also be acceptable from a Shariah perspective. Capital therefore, cannot be used to promote unlawful investments. Investments in the alcohol trade, armaments and gambling are some examples of prohibited investments.

\subsection{Risk taking (Mukhatarah)}

As the Shariah prohibits the guarantee of a fixed return on an investment, the parties must assume some risk in a transaction. Notwithstanding this limitation, taking security over assets is not prohibited, as this is viewed as a prudent means to guard against a contractual breach, wilful wrongdoing or negligence by any of the contracting parties.

\section{Islamic financing structures}

\subsection{Equity structures}

\subsubsection{Partnership financing (Musharakah)}

A Musharakah arrangement is a joint enterprise or partnership in which each partner shares in any profits or losses emanating from that venture. The partners must distribute returns according to a pre-agreed formula based on percentages and agreeing to a fixed profit for one partner would not be compliant with the Shariah. Partners are required to allocate losses according to their capital contributions to the enterprise. Management of the enterprise can be delegated to another entity.

\subsubsection{Silent partnership (Mudarabah)}

Under a Mudarabah arrangement, an investor (Rab al-mal) - usually the financier - provides the capital to an entrepreneur (Mudarib), who is given the sole responsibility to manage the investment. Both the investor and the entrepreneur are entitled to profits, which must be distributed in accordance with a pre-agreed percentage based formula. The investor however bears all the risks of any loss in the absence of any fraud or negligence by the entrepreneur.The entrepreneur cannot provide a guarantee to the investor in respect of the capital amount or any profits from the investment. Many Shariah scholars believe that Musharakah and Mudarabah represent the 
desired forms of Islamic financing.Shariah compliant investments can be structured to yield returns that resemble both equity and debt type returns.

6.2 Debt structures

6.2.1 Cost-plus financing (Murabahah)

A Murabahah is an arrangement in which a seller sells an asset to its customer at a price while disclosing to the customer the relevant profit mark-up. Frequently, the seller (in this case, the financier) appoints the customer as its agent to purchase the assets from a supplier on its behalf in order to make the Murabahah arrangement. The price payable by the customer is invariably deferred, which creates a debt obligation. This structure is commonly employed to facilitate the trade finance activities of Islamic financial institutions

\subsubsection{Lease financing (Ijarah)}

Ijarah is a lease where the benefit available from a specific asset is made available to a lessee in exchange for rental payments for an agreed term. The leased asset must retain value throughout the term of the lease. Assets that are consumed by their use are therefore not permissible lease assets. The lessor assumes the responsibility for major maintenance and insurance of the assets.Different rental amounts may be fixed for different rental periods. A variation of the Ijarah structure is a right to purchase the asset at the end of the lease period (Ijarah muntahiya bi-tamlik). The lessee under this alternative structure agrees to make a capital payment to purchase the asset in question at the end of the lease period.

\subsubsection{Commission to manufacture (Istisna)}

An Istisna is an agreement for the sale of assets that are to be manufactured in accordance with an agreed specification. The sale price must be fixed in advanced, but payments can be made in a single lump sum or in instalments. Until the assets or title to them are delivered to the purchaser at completion, risk in the assets remain with the seller. Islamic project financing deals often employ single Istisna or parallel Istisna structures. In a single Istisna structure, the financier commissions the customer to build the asset. Upon delivery, the customer enters into a lease and purchase arrangement with the financier whereby the financier receives its return of principle and profit.

In a parallel Istisna structure, the first Istisna involves the customer commissioning the financier to build the asset for a price set above the market price. The customer makes a downpayment and the remaining finance amount is usually deferred. The financier then enters into a second (parallel) Istisna with a contractor for the market price and provides the finance until completion. Upon delivery under the second Istisna, the financier in turn delivers the same asset to the customer under the first Istisna. The customer may continue to make instalment payments to the financier for an agreed period. The difference in price between the first Istisna and the second Istisna represents the financier's profit.

\subsubsection{Spot payment for future delivery (Bai Salam)}

Bai Salam is an upfront payment by the purchaser for Shariah compliant assets that the seller undertakes to supply to the purchaser at a date in the future. Although Istisna and Bai Salam appear similar, a key feature of Bai Salam is that the purchase price must be paid in full at the outset and the date for delivery must also be fixed. These are not requirements under an Istisna.

\subsubsection{Tradable and non-tradable certificates (Sukuk)}

Sukuk are certificates that represent pro rata beneficial interests in underlying assets. The underlying assets generate their revenue by means of one of the financing structures discussed above and Sukuk 
holders are entitled to a share of such revenue. The Accounting and Auditing Organisation of Islamic Finance Institutions (AAOIFI) has delineated fourteen different types of Sukuk but in practice, Sukuk issuances have mainly used the underlying structures described above. Sukuk have been structured to yield the sort of returns paid out on conventional bonds so they are usually categorised as debt capital market instruments. It is permissible under the Shariah to trade in Sukuk certificates if the underlying assets, usufructs or services they represent are tangible and identified, such as in Ijara Sukuk. If the underlying assets, usufruct or services are merely described but not identified, such as in a Salam Sukuk, it is not permissible to trade in the certificates as doing so would be tantamount to trading in debt.

\section{Conclusion}

The Islamic finance industry, while still in its infancy, continues to grow rapidly. Cutting-edge financing techniques coupled with a growing amount of capital under Islamic management should ensure continued expansion.

\section{References}

A. Chargi, Origin and Development of Commercial and Islamic Banking Operations, Islamic Economics Volume 18, No. 2, 2005.

A. Ernst, Promoting Islamic Finance and Islamic Banking - A legal analysis of the potential for Islamic Banking products in Germany, Institut für Rechtspolitik an der Universität Trier, 2011

M.U. Draz, F. Ahmad, S. Ali, The Prevailing Skepicism about Islamic Banking and the Re-asseement of Interest-Free Financial Products: An Explanatory Study, Kuala Lumpur/Lanzhou/Lahore, 28 November 2011

M.O. Farooq, Riba, Interest and Six Hadiths: Do We Have a Definition or a Conundrum?, Review of Islamic Economics, Vol. 13, No. 1, 2009

M. El Qorchi, S. Munzele Maimbo and J. F. Wilson, International Monetary Fund and World Bank, Informal Funds Transfer Systems: An Analysis of the Informal Hawala System, paper IMF and World Bank, March 24, 2003.

Quran

\section{Copyrights}

Copyright for this article is retained by the author(s), with first publication rights granted to the journal. 